\title{
The Effect of Free Senior High School Policy on the Lives of Parents and Wards in Ghana
}

\author{
Juabin Matey \\ Divass Services, Bolgatanga -Ghana
}

\begin{abstract}
The free senior high school policy is one of best social and economic intervention policies that openly affect both parents and their wards in senior high school. This realisation is reached on the backdrop of the policy's role in redeeming parents from their economic and financial burden. This study therefore looks at the effect of introducing the free senior high school policy on the economic and social lives of parents and students respectively. A correlational cross-sectional descriptive design was used. Questionnaires were administered on three hundred and thirty-six (336) parents of wards in three senior high schools in the North East and Upper East Regions of Ghana. The study confirms that the introduction of the free senior high school policy relieved the financial burden of parents, especially guardians from rural settlements. Besides, there was lack of adequate stakeholder consultation, hence saddled with implementation challenges. Delay in disbursement of funds for feeding and learning materials presented yet another problem. It is important that governments find sustainable sources of funding the educational system and also ensure the double-track system is regularised into a single-track system by expanding academic user facilities and increasing the numerical strength of both teaching and non-teaching staff in various senior high schools.
\end{abstract}

Keywords: Free Senior High School Education, Operationalisation, Policy, Parents.

\section{INTRODUCTION}

It is quite normal not to find educational issues provoking as much passion as proposals to increase tuition and academic facility user fees in our educational institutions. Reasons for this mismatch are clear; it is not uncommon to find a clear statement of the repercussions of free tuition or high tuition fees (1). Likewise, it has not been that easy to identify what commentators perceive to be the consequence of alternative funding for education. In what seems to be a sharp support to the argument for the free cost of education, the United Nation's advocacy for an all access to education has gained patronage. Among the Sustainable Development Goals, number four addresses the issue of ensuring everyone "completes free, equitable and quality primary and secondary education" (2).

Toeing this line, and as one of the flagship programmes of the New Patriotic Party in Ghana, the Free Senior High School Policy (FSHSP) was implemented. This policy implementation was not without challenges.

*Address of Correspondence: Divass Services, Bolgatanga-Ghana.

E-mail-e.juabin@gmail.com

(Received 08 November 2020; Accepted 16 November 2020) 
It ignited public debate on the sustainability and operationalisation of the system. Through the double-track, the shift system allows for students to go to school in batches, thus, whiles one batch is on holidays, the other is engaged in learning at school. This makes it possible to find students at home while their colleagues are in school. According to Botchway et al. this system is seen through improvement of school curricular and attendance, but appears to fail in delivery (3). Although there are many who have lauded the introduction of the double-track system which has given the graduants of the Junior high school the opportunity to have their way freely into the SHS, the question that rings in the minds of the concerned Ghanaian is; does the system have the quality needed to turn out well baked students as future leaders?

The antagonists of this policy however argue that it was a political gimmick and could not stand the test of real time. The argument that a poor individual cannot pay for education is deceptive. And indeed, the question of who a poor person is became contentious. Is the person a college calibre student? Failure to comprehend a college calibre student is a reflection of ignorance of two economic facts (1). One is the availability of human wealth that abounds our societies but untapped or unnoticed. The second economic fact is the difference between the current earnings of the wealthy and the enhanced value of the poor from college training through the FSHSP.

Social and economic analysts on the other side contend that education has the power of breaking the vicious cycle of poverty on the African continent (4). Education, according to this school of thought, melts illiteracy and ignorance. It stimulates innovation, bringing about inventions making the individual famous and globally popular (4). Most Ghanaian families barely survive economic conditions with their children seen dropping out of school for their inability to pay school fees thereby hitting the snug. With the implementation of the FSHSP, the economic woes of parents are seen to reduce considerably. This policy is in perfect agreement with the provisions of the International Covenant on Economic, Social and Cultural
Rights (ICESCR) of which Ghana is a signatory (5). These provisions allow for the disposable incomes of parents to appreciate. All these benefits notwithstanding, the operationalisation of the programme needs much to be desired. Planning at the outset was poorly done without giving enough time for the programme to find its proper footing. Planning a project, executing and implementing it need more time for viability. The FSHSP was trivialized and downplayed as it lacked proper and adequate planning time. The synergists have praised this policy for being good but described as one on the verge of collapse due to poor planning. Not only this, sustainability of the programme is yet another consideration that has to be remembered. In his article on financial benefits of FSHSP to parents and the economy, Okrah pointed out that, benefits of the policy are enormous as it enables farmers to gain through government purchases of their farm produce, thereby giving them ready market (5). He again revealed that businessmen and women who rely on equity and debt financing for their enterprises will be saved the hassle. Research study also explains; by not paying wards school fees, the monies could be used to invest in assets which go a long way to creating employment opportunities in the economy (5).

It was identified that a number of problems associated with the operationalisation of the FSHSP through the double-track system (3). Apart from the swelling figures of teenage pregnancies in our SHSs, the double-track, Researcher lamented, could encourage truancy among students. It breeds fake holiday students as students who are scheduled to be on vacation may not be genuinely identified from the lazy ones in the batch supposed to be in school. This is detrimental to the taxpayer as he or she continues to pay for services not appropriately received. The system has the potential for fewer contact hours with tutors. Parents are seen literally spending more than they previously spent on education through attendance of extra classes during holidays by wards to prevent them from indulging in unfruitful activities and other social vices. Similarly, the double-track system creates unfairness as some schools are seen running a full time (normal school

(2)

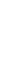

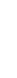


schedules as before in single-track) while others go double-track, limiting contact hours with tutors.

Talking on Adom FM, Dr. Daniel Yielpiere, a senior research fellow at the University of Education, Winneba, bemoaned the longevity of the stay at home by students as it escalates social vices in our societies. Dr. Daniel Yielpiere added that; the stay at home by students during a break of one of the tracks will make "the devil find a job for idle hands". "The objectives of the double-track system are to create room to accommodate an increase in enrollment, reduce class size, increase contact hours and increase the number of holidays" (6).

\section{LITERATURE REVIEW}

\section{Concept of Educational Reforms}

Various definitions have been suggested intended to mean education. Researcher refers to education as the act of imparting skills, knowledge, customs and values from one individual or generation to the other $(7,8)$. Being the panacea for social and economic development, education is globally considered as a basic human right. The Universal Declaration on Human Rights in 1984 (Article 26) enjoins every individual of able body and mind and willing, to be given free right to education at basic and subsequent stages where applicable $(8,9)$. Result of the Asumadu studies in 2019 defines reforms as enacted attempts to correct an anomaly in an organizational setup (8). Educational reforms or policies, according to Psacharopoulos, 1989 (10), are decisions by policy makers tailored at bringing changes to the educational system that affect policy output. According to Gold, 2002 (11), change is constant in our educational system, especially the learning standards, funding and cost bearing (2).

Empirically, Mensah, 2019 finds that although the FSHSP is plausible by way of increased enrolment numbers, it lacked adequate stakeholder consultation (2). He adds that the introduction of the FSHSP lacked adequate funding and logistics among others. Similarly, Asumadu, 2019 identifies reduction in economic burden on parents and guardians by way of absorbing tuition and feeding fees, recruitment of teachers to ease the unemployment menace as positive aspects of the system (8). Reechoing the position of (2) on the negatives of the policy, Asumadu in 2019 found overcrowding and pressure on existing infrastructure which virtually increases maintenance cost (8). By way of purchasing farm produce from farmers to feed school children, it gives farmers ready market and eliminates the activities of middlemen thereby empowering our local farmers economically (5). Elaborating on how the FSHSP negatively impacts the society through the double-track system, (12) captured the ranking member of education committee in Ghana's Parliament, Peter Norsy-Kotoe as saying; "within a spate of one year (2018-2019), over 1,433 girls at Senior High Schools across the country were impregnated and dropped out of school".

\section{METHODOLOGY}

Data were obtained using a cross sectional correlational research. This is a fixed nonexperimental descriptive survey where the researcher measures the two variables of interest with little or no attempt to control extraneous variables and then assesses the relationship between them. Unlike the experimental descriptive survey, correlational descriptive survey only looks at beliefs, opinions and attitudes of participants without manipulating the independent variables in the study $(13,14)$. Besides, Saunders et al. (15) emphasize that a survey strategy allows for data collected to be quantitatively analyzed using descriptive and inferential statistics. I basically assessed the effect of free senior high education on parents and students in the North East and Upper East Regions of Ghana.

The study's population comprised the parents of students from Bunkpurugu, Nakpanduri and Garu-Tempane senior high schools. A total of 336 participants were purposively selected to respond to questions contained in the questionnaire. These participants were those who were real rural settlers and had challenges financially and economically. This was made possible through 
consultation with tutors to identify lifeline students. Aside administration of questionnaires, Focused Group Discussions
(FGDs) was also organized with these participants on two occasions to solicit opinions.
INDEPENDENT VARIABLE

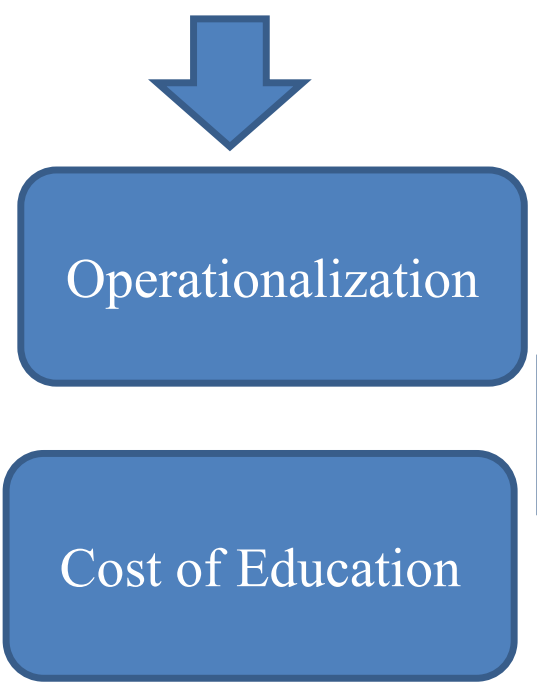

DEDPENDENT VARIABLE

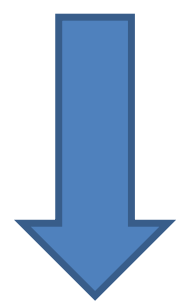

$>$ Parents' Economic Live

$>$ Students' Social Live

FIGURE 1: Conceptual Framework

Source: Researcher's Own Construct (2020)

\section{STUDY VARIABLES}

\section{Outcome Variable}

The economic lives of parents and social lifestyles of students were sub-categories of the dependent variable; Lifestyle. To effectively analyze data, the dependent variable (Lifestyle) assumed categorical values (Yes $=1$, (when given a value of 4 and 5 for a given statement) and No $=0$ (when given a score of 3, 2 and 1 for each provided statement). Each subset was assumed good (when rated a score of 4 or 5 ) and lifestyle not good (when rated a score of 3, 2 or 1). Responses that fell within 1, 2, \& 3 were lumped as "No" $=0$, while scores 4 and 5 also grouped as "Yes" 1 . The object of this categorization was to obtain results for a "No" and "YES" responses.

\section{Predictor Variable}

The operationalization of the FSHSP and the free cost of education were lumped as the independent variables.

\section{Model Specification}

Given the fact that the study had more than one independent variable, multiple-regression model was adopted. According to (16), a multiple-regression model is used when a group of independent variables together predict a given dependent variable. A multiple-regression model is used to measure the effect of two or more independent variables on a single dependent variable which may have subcategories. The following equation was used; 
LIFESTYLE $=\beta_{0}+\beta_{1}($ OPERA $)+\beta_{2}($ COSTEDU $)+\varepsilon$

Where:

LIFESTYLE = is the dependent variable of the study measured in terms of parents economic conditions and social behavioural change in students

FSHSP $=$ Free Senior High School Policy and represents the independent variable annexed by cost of education (COSTEDU) and operationalisation of the policy (OPERA)

$\beta_{0}=$ Regression Coefficient Constant

$\beta_{1}=$ Slope of the regression equation with regards to operationalisation of FSHSP

$\beta_{2}=$ Slope of regression equation with regards to cost of education

$\varepsilon=$ Margin of error

\section{Reliability and Validity Tests}

Reliability test measures the extent to which the study instrument produces the same results having undergone repeated trials (16). Cronbach, 1951 stated that alpha reliability and internal consistency method was used to test the instrument (17). This gauges the accuracy with which the data collection instrument (questionnaire) measures the variables under consideration. According to Mugenda and Mugenda , 2003 a coefficient alpha value of 0.70 or greater is accepted(16). Similarly, validity measures how representative data analysis reflects the phenomenon in the study. It ensures that the research instrument actually measures exactly what it was intended for (16).

\section{RESULTS AND DISCUSSION}

This section is aimed at narrating findings, trying to interpret or evaluate and provide a link to the discussion section. The results are narrated in accordance with research objectives. Inferential statistics were used to impugn meaning into analysed data. The inferential statistical analysis helped to establish the link between the independent variable (cost of education and operationalisation of the policy in the form of the double-track system) and the dependent variable (economic conditions and social lifestyle).

\section{Test Results for Reliability}

Table 1: Dependent and independent variable reliability statistics

\begin{tabular}{lcc}
\hline Statement & Coefficient-Alpha & Sub-values \\
\hline Free Senior High School Policy & 0.794 & 6 \\
Economic conditions of Parents & 0.812 & 5 \\
Social Lifestyle of Students & 0.774 & 6 \\
\hline
\end{tabular}

Source: Cronbach's Alpha Test Run

Reliability test for individual variables requires that a threshold mark of $70 \%(0.70)$ for acceptance be achieved. 


\section{Categorization of Respondents}

The study determined the number of categories of respondents to participate in providing responses to questions raised in the questionnaires and their location for easier survey. Table 2 gives details of the respondent population and location.

Table 2: Selection of respondents

\begin{tabular}{lcl}
\hline Location / School & Number of Respondents & Percentage \\
\hline Bunkpurugu Senior High Sch & 126 & 38 \\
Nakpanduri Senior High Sch & 105 & 31 \\
Garu-Tempane Senior High Sch & 105 & 31 \\
Total & 336 & 100 \\
\hline
\end{tabular}

Data Source: Field Survey (2020)

A total of three hundred and thirty six (336) participants provided responses to the questionnaires. Out of this number, 38 percent came from parents whose children attend Bunkpurugu Senior High School whilst 31 percent each of responses came from parents of students from Nakpanduri Senior High School and Garu-Tempane Senior High School respectively.

\subsection{3: Effect of Free Senior High School Policy on Economic and Social Lives of Parents and Students}

Table 3: Economic conditions of Parents

\begin{tabular}{lcc}
\hline Response & $\begin{array}{c}\text { Number of } \\
\text { respondents }\end{array}$ & Percentage \\
\hline Yes & 311 & 92.6 \\
No & 25 & 7.4 \\
Total & $\mathbf{3 3 6}$ & $\mathbf{1 0 0}$ \\
\hline
\end{tabular}

Data Source: Researcher's Own Computation from Field Data (2020)

A question on whether the introduction of the FSHSP is helpful to parents recorded an overwhelming positive response of 92.6 percent. Only 7.4 percent was sceptical about policy relevance. In fact, respondents who made up this category were neutral in response, but as a rule under the methodology, a neutral response is regarded as "NO", since it corresponded with a score of 3 which falls under a "NO" category. Those who responded positively explained that parents and guardians of wards have been relieved of their financial and economic burden and could now invest what is regarded as surplus or appreciated income into other viable ventures. These findings are in sharp agreement with those by Asumadu (2019) who identified reduction in economic burden on parents and guardians by way of absorbing tuition, feeding fees and recruitment of teachers to ease the unemployment menace. In a focus group discussion, respondents told the researcher how the difficulty of putting food on the table for families has been overcome. A section of the participants explained how petty misunderstandings between couples over economic sustenance have considerably reduced. In the case of Nsiah 2019 (4), he similarly found that some Ghanaian families barely survive the hash economic conditions with their children even dropping out of school due to parents' inability to pay school fees, but for the implementation of the FSHSP, the economic woes of parents are now a thing of the past. 
Table 4: Social Lifestyle of Students

\begin{tabular}{lcc}
\hline Response & $\begin{array}{c}\text { Number of } \\
\text { respondents }\end{array}$ & Percentage \\
\hline Yes & 91 & 27 \\
No & 245 & 73 \\
Total & 336 & 100 \\
\hline
\end{tabular}

Data Source: Researcher's Own Computation from Field Data (2020)

Table 4 presents a different response trend which is quite on the opposite of what was witnessed in Table 3, in answering questions on whether the introduction of the FSHSP (eg through the double-track system especially) impacted positively on the social lives of school children. It was established that whilst 73 percent of participants responded in the negative, 27 percent rather preferred to stay on the fence, (implying a "NEUTRAL" response) or gave a "YES response. Indeed, those who lamented on how the double-track system negatively affected their wards explained that, during holidays their wards are in most instances seen engaging in a number of social vices such as internet scamming, "Soccer Betting" on the internet etc (a form of lottery). Another group (156/245[63.7\%]) of those who claim the introduction of the FSHSP through the double-track system brought untold social evil, expressed disgust about the ascendency of teenage pregnancies in various SHSs. This response, the researcher noted, was in line with that captured in an article by Ayamga, 2019 (12), where a ranking member on the education committee in Ghana's Parliament, Peter NorsyKotoe, bemoaned the increase in teenage pregnancies in our SHSs. The statement added that within the 2018 / 2019 academic year alone, 1,433 students across our senior high schools nationwide were impregnated and had to drop out of school (12).

Again, it came up at the group discussion with some parents that despite the benefits that the double-track system brings such as increase enrolment numbers, it breeds unfairness, laziness and truancy. This was observed to be in consonance with the position of Botchway, 2019 (3) who identified problems associated with the operationalisation of the FSHSP through the double track system to include encouragement of truancy among students and laziness among others.

\section{Multi-regression Analysis}

A regression analysis was conducted to test the effect of free senior high education policy (annexed by operationalisation and cost of education) on the economic and social life style of parents and students respectively. Microsoft Excel was used to turn out the regression results. Table 5 gives details of the Regression Model Summary.

Table 5: Regression Model Summary of Operationalisation of the FSHSP

\begin{tabular}{ll}
\hline & $\begin{array}{l}\text { Regression } \\
\text { Statistics }\end{array}$ \\
\hline Model (R) & 0.652 \\
R-Square & 0.425 \\
Adjusted R-Square & 0.420 \\
Std. Error & 0.114 \\
\hline
\end{tabular}

Predictors: (Constant), Independent Variable $=$ Operationalisation of the FSHSP

Source: Researcher's own construct (2020)

The relationship between the study variables

was established that positive relationship exists was done by using the regression coefficient. It between studied variables, reflective in the 
approximate R-value (0.652) [Table 5]. The RSquare value $(0.43)$ or about 43 percent explains the variance in the power of the independent variable (Operationalisation of FSHSP [annexed by double-track system]) to influence the outcome variable (social Lifestyle of students. What it tells the readership is that, 57 percent of the students' social lifestyle is influenced by other latent factors not captured in this study.

Table 6: Analysis of Variance (ANOVA)

\begin{tabular}{lcclcc}
\hline & Sum of & Mean & & \\
& Square & Df & Square & F & Sig \\
\hline Regression & 24.23 & 1 & 51.77 & 28.73 & 0.000 (a) \\
Residual & 9.67 & 335 & 0.411 & & \\
Total & 33.90 & 336 & & & \\
\hline
\end{tabular}

Source: Researcher's own construct (2020)

It is evidenced from Table 6 that with a significance value of 0.000 (a), less than 1 percent level, the data could be relied upon to make a conclusion. The $p$-value $=0.000<0.05$, $\mathrm{R}=0.652, \mathrm{R}^{2}=0.425$. This is a suggestion that the nature of the operationalisation of the FSHSP (double-track system) significantly predicts the social lifestyle of students in our SHSs across the nation (see Table 6). By extension therefore, there is a statistically significant relationship between the FSHSP annexed by operationalisation and social lifestyle of students and accepted based on the results of the regression analysis. The $R^{2}$ (0.425) value indicates that approximately 43 percent of variations in social lifestyle of students is accounted for by the linear combination of the independent variable (the nature of the operationalisation of the FSHSP annexed by the double-track system).

Table 7: Regression Model Summary of Cost of the FSHSP

\begin{tabular}{ll}
\hline & Regression \\
Statistics
\end{tabular}

Predictors: (Constant), Independent Variable $=$ Cost of funding education

Source: Researcher's own construct (2020)

Per results in Table 7 , the coefficient of determination indicated by $\mathrm{R}^{2}=0.956$ suggests that about 96 percent of the economic conditions of parents of wards in our senior high schools, especially in the rural settlements is explained by the free school fees that is occasioned by the FSHSP. By extension therefore, parents of wards have other factors not explained by study variables that make them comfortable economically. These factors are outside the current model reflected in the error term. It must be stressed that, the correlation coefficient given at about 0.980 signifies that there is a strong positive correlation between the effect of the FSHSP and the economic conditions of parents. 
Table 8: Analysis of Variance (ANOVA)

\begin{tabular}{lcclcc}
\hline & Sum of & Mean & & \\
& Square & Df & Square & F & Sig \\
\hline Regression & 162.0 & 1 & 70.77 & 5.021 & 0.009 \\
Residual & 7.11 & 335 & 14.07 & & \\
Total & 169.11 & 336 & & & \\
\hline
\end{tabular}

Source: Researcher's own construct (2020)

The independent variable was Cost of funding free senior high education (COSTEDU). The dependent variable was Life-style of parents. The result of the model of economic condition of parents was $\mathrm{F}(1,335)=5.02, \mathrm{p}=0.009<0.05$, $\mathrm{R}$-value $=0.978, \mathrm{R}^{2}=0.956$, which gives $\mathrm{a}$ suggestion that government policy measures undertaken (COSTEDU) predicts economic lives of parents through lessening the economic and financial burden of parents significantly.

\section{CONCLUSION}

If for nothing at all, the introduction of the FSHSP has been very beneficial to parents and guardians through reduction in their financial burden. It is one of economic policies in the past decade in Ghana that strategically targeted poverty alleviation. The operationalisation (double-track system) of the FSHSP is quite helpful due to the infrastructural deficit at our senior high schools. Aside that, the policy lacked adequate stakeholder consultation as it was saddled with hasty implementation.

\section{RECOMMENDATIONS}

Sustainable sources of funding the FSHSP such as the Heritage Fund and an established Fund purposely for activities of the FSHSP are recommended to the government. This is critical in the face of the financial and economic burden that the policy takes off parents' budgets. Operationalisation of the policy should be given a second look regarding the double-track so as to curb the menace of teenage pregnancies and other social vices engaged in by the male students during holidays which are already a force to reckon with in the system prior to the implementation of FSHSP.

\section{CONFLICT OF INTEREST}

There is no conflict of interest in this present study. This research work is not a part of any other studies and it is our original work.

\section{REFERENCES}

1. Alchian AA. The economic and social impact of free tuition, Libery Press, Indianapolis. 1977.

2. Mensah DKD. Teachers' perspective on implementation of the double track senior high school system in Ghana. International Journal of Emerging Trends in Social Science. 2019; 5 (2): 47-56.

3. Botchway J. Education: Disadvantages of the double track system. 2019. https://newsghana24.com/educationdisadvantages-of-the-doubletrack-system/

4. Nsiah D. Free education in Ghana: Advantages and disadvantages. 18 th $^{\text {th }}$ November, 2019; accessed from https://yen.com.gh/108674-freeeducation-ghana

advantages-disadvantages.html

5. Okrah BD. Financial benefits of free SHS policy to parents and economy. 4 October 2017. https://yen.com.gh/108674free-education-ghana advantages-disadvantages.html 6. Adomonline.com. Double tracking system; a recipe for social crises - Dr Yielpieri. Thursday, 26 July 2018. https://www.ghanaweb.com/GhanaHomePage/NewsArchiv e/Double tracking-system-a-recipe-for-social-crises-DrYielpieri-672125

7. Adu-Gyamfi S, Donkoh WJ, Addo A. A. Educational reforms in Ghana: Past and present. Journal of Education and Human Development.2016; 5(3): 158-172.

8. Asumadu E. Challenges and prospects of the Ghana free senior high school policy: The case of SHS in Denkyembour District, University of Ghana. 2019.

9. UNESCO Global Monitoring Report: The Role of the Organization and Social Context of Schools. 2005. http://portal.org/education.

10. Psacharopoulos G. Time trends of the returns to education: Cross national evidence. Economics of Education Review. 1989; 8(3): 225-231.

11. Gold KM. Schools in: The history of summer education in American public schools. New York: Peter Lang. 2002.

12. Ayamga E. Double track system has caused 1,433 teenage Pregnancies Minority. 2019.

13. Fraenkel JR. Wallen NE. How to design and evaluate research in education, 2003. (5th ed.). New York: McGrawHill Publishing Co.

14. Bushman B.J, Huesmann LR. Effects of televised violence on aggression. 2001. In D. Singer \& J. Singer (Eds.), Handbook of children and the media. 223-254, Thousand Oaks, CA: Sage. 
15. Saunders M, Lewis P, Thornhill A. Research methods for business students. 2012. 6th ed. Harlow, Essex: Pearson Education Limited.

16 Mugenda 0 M, Mugenda AG. Research methods: Quantitative and qualitative Approaches. 2003. Acts Press, Nairobi-Kenya.

17. Cronbach LJ. Coefficient alpha and the internal structure of tests. Psychometrika. 1951;16(3): 297-334. 